Hosany, S., Prayag, G., Van Der Veen, R., Huang, S. and Deesilatham, S. (2016) 'Mediating Effects of Place Attachment and Satisfaction on the Relationship between Tourists' Emotions and Intention to Recommend', Journal of Travel Research

DOI: https://doi.org/10.1177/0047287516678088

This document is the authors' Accepted Manuscript.

License: https://creativecommons.org/licenses/by-nc-nd/4.0

Available from RADAR: https://radar.brookes.ac.uk/radar/items/476f18c5-deb8-44ac-b366-ae22f4bc6bd3/1/

Copyright $(\subseteq$ and Moral Rights are retained by the author(s) and/ or other copyright owners unless otherwise waved in a license stated or linked to above. A copy can be downloaded for personal non-commercial research or study, without prior permission or charge. This item cannot be reproduced or quoted extensively from without first obtaining permission in writing from the copyright holder(s). The content must not be changed in any way or sold commercially in any format or medium without the formal permission of the copyright holders. 


\title{
Mediating Effects of Place Attachment and Satisfaction on the Relationship between Tourists' Emotions and Intention to Recommend
}

\author{
Sameer Hosany, Girish Prayag, Robert Van Der Veen, Songshan (Sam) Huang, and \\ Siripan Deesilatham
}
[This a post-print version of the manuscript accepted for publication in Journal of Travel Research. For full citation, refer to the published version - available using the DOI: $10.1177 / 0047287516678088]$

\begin{abstract}
This study develops and tests a model based on the developmental theory of place attachment. The model considers the influence of tourists' emotions on place attachment and the mediating effects of satisfaction and place attachment on the relationship between tourists' emotions and intention to recommend. The model was tested using data collected from 464 international tourists at the end of their trip to Thailand. Results show that positive emotions, negative emotions and satisfaction are significant determinants of place attachment. In particular, negative emotions display a positive relationship with place attachment. In addition, only satisfaction mediates the relationship between tourists' emotions and intention to recommend. Findings highlight the need for researchers to incorporate emotions in modeling place attachment and offer implications for marketers promoting Thailand as a tourist destination.
\end{abstract}

Keywords: tourists' emotions, place attachment, satisfaction, intention to recommend, developmental theory 


\section{Introduction}

Existing studies on affective consumer relationships investigates concepts of interest such as brand attachment (Thompson, MacInnis and Park 2005), possession attachment (Ahuvia 2005), destination attachment (Yuksel, Yuksel and Bilim 2010), and place attachment (Vlachos, Theotokis, Pramatari, and Vrechopoulos 2010). This rich body of research recognizes that consumers develop attachment to different situations, objects and entities. Prior research investigates attachment to festivals (Lee, Kyle, and Scott 2012), hot spring resorts (Su, Cheng and Huang 2011), destinations (Prayag and Ryan 2012; Yuksel, Yuksel and Bilim 2010), heritage sites (Poria, Reichel and Biran 2006) and other natural areas (Tonge, Ryan, Moore and Beckley 2015). Antecedents of place attachment include motivation to visit (Kyle, Mowen and Tarrant 2004), destination image (Chen and Phou 2013; Prayag and Ryan 2012), destination attractiveness (Cheng, Wu and Huang 2013; Hou, Lin and Morais 2005), service quality (Su, Cheng and Huang 2011), destination personality and trust (Chen and Phou 2013), and personal involvement (Gross and Brown 2008; Hou, Lin and Morais 2005; Prayag and Ryan 2012).

A significant lacuna in tourism research remains the influence of emotions on place attachment. The literature on environmental psychology recognizes an overlap between emotions felt toward a place and place attachment (Halpenny 2010; Low and Altman 1992; Manzo 2003). Morgan (2010: 11) notes that "most authors recognize an emotional or affective component in the concept of place attachment but the word emotion, like place, has an easy-to-understand, hard-to-define quality, making place attachment if anything, more conceptually elusive than place itself'. Place-people relationship consists of an array of positive emotions such as love, pride, and 
contentment (Scannell and Gifford 2010). But, attachment to the environment is not always positive (Manzo 2005). Unhappy experiences can lead to place aversion (Scannell and Gifford 2010). The environmental psychology literature uses the term 'place affect' to describe both positive and negative emotions that visitors feel toward a place (Halpenny 2010). In fact, several studies have modelled place affect (Halpenny 2010; Ramkissoon and Mavondo 2015; Ramkissoon, Smith and Weiler 2013) as a sub-dimension of place attachment.

Yet, prior research recognizes that emotions and place attachment are related but distinct constructs (e.g. Altman and Low 1992; Hernandez, Hidalgo, Salazar-Laplace, and Hess 2007; Morgan 2010). Accordingly, based on Morgan's (2010) developmental theory of place attachment, this study models emotions are antecedents of place attachment. Morgan (2010) suggests that a pattern of emotional experiences toward a place develops, with time, into a bond known as place attachment. Consumer research supports the idea that emotions felt during the consumption process are retrieved to evaluate post-consumption behaviors and these emotions influence product/brand attachment (Mugge, Schifferstein, and Schoormans 2010; Orth et al. 2012). Furthermore, in a recent study, Hosany et al. (2015) provides strong evidence that in tourism, emotions achieve discriminant validity with the place attachment construct. However, Hosany et al. (2015) did not explicitly investigate the structural relationships between emotional responses and place attachment.

The purpose of this study is to test a conceptual model linking tourists' emotions, place attachment, satisfaction and intention to recommend. The current research focuses on tourists' holistic and hedonic experiences at a popular destination, Thailand. Vacations are primarily consumed for hedonic purposes (Otto and Ritchie 1996). The emphasis on hedonic tourist experiences remains popular among tourism 
researchers (Knobloch, Robertson, and Aitken, 2016) The proposed framework (Fig.1) draws on existing theorizations cutting across various disciplines such as environmental psychology (e.g. Halpenny 2010; Morgan 2010; Manzo 2005), marketing (Orth, Limon and Rose 2010; Su, Cheng and Huang 2011; Vlachos et al. 2010), and tourism (Prayag and Ryan 2012; Ramkissoon, Smith and Weiler 2013; Yuksel, Yuksel and Bilim 2010). The model shows that tourists' emotions (positive and negative) are antecedents of satisfaction and intention to recommend. Place attachment and satisfaction mediates the relationship between tourists' emotions (positive and negative) and intention to recommend. Finally, satisfaction influences intention to recommend. From a practical perspective, the model posits that an understanding of the emotions that drive place attachment will enable destination marketers to formulate effective advertising and communication strategies.

The contribution of this study is four-fold. First, this research responds to recent call for tourism researchers (e.g. Hosany et al. 2015) to examine the relationship between tourists' emotional responses (positive and negative) and place attachment. Existing studies can be classified in two main categories; the first group focuses on emotions and satisfaction in predicting future intentions or loyalty (Grappi amd Montanari 2011; Prayag, Hosany and Odeh 2013; Yuksel and Yuksel 2007). The second research stream includes satisfaction and place attachment along with other variables (Chen and Phou 2013; Prayag and Ryan 2012; Su, Cheng and Huang 2011) to predict future intentions or loyalty. There is currently no study that examines the relationships between emotions, satisfaction and place attachment in the context of a tourist destination. Second, in the environmental psychology literature, 'place affect' (Halpenny 2010; Low and Altman 1992) is used to describe the emotions of an individual toward a particular place and is not considered as a distinct concept from 
place attachment. Similarly, in the marketing literature, brand attachment, a concept related to place attachment, has been originally conceptualized using emotional dimensions such as affection and passion (Thompson, MacInnis and Park 2005) and/or mostly positive emotions (Park et al. 2010). However, Hosany et al. (2015) show that emotions and place attachment are related but distinct constructs. In this study we extend existing research (e.g. . Chen and Phou 2013; Prayag and Ryan 2012; Veasna, Wu and Huang 2013; Yuksel, Yuksel and Bilim 2010) and hypothesize emotions as determinants of place attachment.

Third, the study contributes to the debate on the relationship between place attachment and satisfaction. Satisfaction is conceptualized as either an antecedent (Chen and Phou 2013; Lee, Kyle and Scott 2012; Su, Cheng and Huang 2011; Zenker and Rütter 2014) or outcome of place attachment (Hwang, Lee and Chen 2005; Prayag and Ryan 2012; Ramkissoon, Smith and Weiler 2013; Veasna, Wu and Huang 2013; Yuksel, Yuksel and Bilim 2010). In this study, based on the developmental theory of place attachment (Morgan 2010), we confirm that satisfaction is an antecedent of place attachment. Fourth, we propose that satisfaction and place attachment mediates the relationship between tourists' emotions and intention to recommend. Prior studies in tourism (e.g. Prayag and Ryan 2012; Veasna, Wu and Huang 2013; Yuksel, Yuksel and Bilim 2010) fail to consider the mediating effects of place attachment. To benefit theory development, mediators provide useful information on 'how' or 'why' an independent variable predicts the outcome variable (Bennett 2000; Wu and Zumbo 2008).

\section{Conceptual Background and Hypotheses Development}




\section{The Concept of Place Attachment}

No single accepted definition or systematic theory of place attachment exists (Low and Altman 1992; Lewicka 2011; Scannell and Gifford 2010). In this study, drawing on Morgan's (2010: 12) developmental theory, place attachment is defined as "an affective bond to a particular geographical area and the meaning attributed to that bond". The developmental theory of place attachment attempts to bring together attachment theories in psychology (e.g. Bowlby 1982) and theories of place. According to this theory, place attachment emerges from social interactions and one's evaluation of the environment. Place attachment is seen as a developmental process in which experiences during the trip are internalized at the unconscious level and subjectively manifests into an attachment to a place (Morgan, 2010). Given the 'developmental' nature of place attachment and the meanings attributed to a place based on an individual's interactions with the place, it is important to specify a time, place and context when operationalizing place attachment. Place attachment is a meaningful construct at the end of a tourist trip, when all tourism experiences are complete. From the perspective of people-environment interactions, place attachment would thus represent an overall connection or bond between a person and a location (Tuan, 1980).

Place attachment has been studied extensively in tourism (e.g. Hou, Lin and Morais 2005, Gross and Brown 2008; Lee, Kyle and Scott 2012; Prayag and Ryan 2012; Ramkissoon, Smith and Weiler 2013; Yuksel, Yuksel and Bilim 2010; Veasna, Wu and Huang 2013). Studying visitors' attachment to national parks and recreational areas to predict pro-environmental behavior dominate existing research tradition (e.g. Hwang, Lee and Chen 2005; Ramkissoon, Weiler and Smith 2013; Tonge et al. 2015). However, the emotional aspects of the tourism experience have been ignored in 
predicting place attachment (Orth et al. 2012). In addition, existing studies focus on the influence of place attachment on post-consumption behaviors such as loyalty (e.g. Chen and Phou 2013; Prayag and Ryan 2012) but ignore the mediating role place attachment plays on the relationship between on-site tourism experiences (such as emotions) and post-consumption behaviors.

Many studies recognize two dimensions of place attachment: place identity and place dependence. Place identity refers to the symbolic importance of a place as a repository for emotions and relationships that give meaning and purpose to life (Williams and Vaske 2003). Place identity is described as a component of self-identity that increases one's sense of belonging to a place (Relph 1976; Tuan 1980) and enables individuals to express and affirm their identity (Kyle, Mowen and Tarrant 2004). Place dependence reflects on "how well a setting serves goal achievement given an existing range of alternatives" (Jorgensen and Stedman 2001: 234). Place dependence is a form of functional attachment, providing features and conditions that support the achievement of specific goals or desired activities (Williams and Vaske 2003). The functional attachment "is embodied in the area's physical characteristics and related to specific activity needs" (Su, Cheng and Huang 2011: 2724). Repeat visitation contributes to place attachment (Moore and Graefe 1994) but recent studies (e.g. Cheng and Kuo 2015) confirm that individuals form bonds to places not visited previously.

\section{Tourists' Emotions}

Emotions are distinct from moods (Russell 1980). Moods are mild affective states that are easily induced, transient and not attributable to a specific stimuli or object (Gardner, 1985). Emotions are affective states characterized by episodes of 
intense feelings associated with a specific referent (such as a person, an object, or an event) and instigate specific response behaviors (Cohen and Areni 1991). The psychology literature offers two major theoretical approaches to study emotions: categorical (emotion specificity) and dimensional (valence based). Categorical approaches theorize emotions as a set of idiosyncratic affective states (e.g. joy, disappointment, surprise) (see Izard 1977; Plutchik 1980). Dimensional approaches conceptualize emotions using few dimensions such as positive and negative (Watson, Clark, and Tellegen 1988), or pleasure and arousal (Russell 1980). Measurement of emotions in tourism has favored the valence-based approach. Summary dimensions, positive and negative (e.g. del Bosque and San Marti 2008; Grappi and Montanari 2011) or pleasure and arousal (e.g. Bigné, Andreu, and Gnoth 2005; Yuksel and Yuksel 2007) are common. The dimensional approach gives a more parsimonious account of emotional experiences (Lazarus 1991) and usually influences satisfaction and behavioral intentions (del Bosque and San Martin 2008; Grappi and Montanari 2011).

Researchers often adapt scales from psychology to measure emotions in tourism. Commonly adapted valence based scales include Mehrabian and Russell's (1974) Pleasure, Arousal, and Dominance (PAD) and Watson, Clark, and Tellegen's (1988) Positive Affect and Negative Affect Scales (PANAS). However, researchers have questioned the applicability, reliability, and validity of psychological emotion scales in consumer studies (see Laros and Steenkamp 2005; Schoefer and Diamantopoulos 2008). Hosany and Gilbert (2010) further note that existing emotion scales from psychology fail to take into account tourism and destination-specific characteristics. Recognizing the need to measure the diversity and intensity of tourists' emotional responses, Hosany and Gilbert (2010) developed the Destination 
Emotion Scale (DES). The DES consists of 15 items representing three emotional dimensions of joy, love and positive surprise. Lee and Kyle's (2013) Festival Consumption Emotions (FCE) scale also identified joy, love and positive surprise as key emotions, together with a negative dimension. Studies have also shown that emotions vary throughout the tourism experience (Lin, Kerstetter, Nawijn and Mitas 2014; Nawijn 2011; Nawijn, Mitas, Lin and Kerstetter 2013).

\section{The Relationship between Tourists' Emotions and Place Attachment}

\section{Positive Emotions and Place Attachment}

Relationship theory supports a direct link between consumer affective experiences and brand attachment (Grisaffe and Nguyen 2011; Orth, Limon and Rose 2010). Strong attachment is associated with a sense of affection, love and passion (Mugge, Schifferstein, and Schoormans 2010). Orth, Limon and Rose (2010) confirm that pleasure and arousal are positively related to brand attachment. In a destination context, place represents the attachment figure, and consistent with Morgan's (2010) developmental theory, positive emotions toward a place will reinforce a sense attachment through person-place interactions. Emotions related to the destination experience contribute to the formation of place attachment. Accordingly, the following hypothesis is formulated:

$\mathbf{H}_{1}$ : Positive emotions have a positive effect on place attachment

\section{Negative Emotions and Place Attachment}

Tourism experiences are not devoid of negative emotions (Hosany and Prayag 2013). However, there is a lack of negative emotions in tourists recalled experiences. 
For example, Nawijn (2011) and Nawijn et al. (2013) report that tourists' rated their holiday experiences low in terms of negative emotions. Findings are consistent with the 'rosy view' effect (Mitchell et al. 1997) where negative occurrences in people's retrospective assessments of events are mitigated and positive experiences magnified (Lee and Kyle 2012). However, relationships people associate to places are not always positive and people can develop aversion to certain places (Relph 1985). Some places are oppressive and as a result people feel less connected to them (Relph 1976). The place attachment literature overemphasizes positive emotions toward places (Trentelman 2009) and how negative emotions contribute to place attachment is under researched (Manzo 2005). Hence, the study proposes the following hypothesis:

$\mathbf{H}_{2}$ : Negative emotions have a negative effect on place attachment

\section{The Relationship between Tourists' Emotions and Satisfaction}

\section{Positive Emotions and Satisfaction}

Satisfaction is a positive reaction resulting from favorable appraisals of consumption experiences (Oliver 1997). Some research in tourism follow a cognitive approach and conceptualize satisfaction as an evaluation of whether or not expectations are met (e.g. Eusébio and Vieira 2013). Other studies operationalize satisfaction as an affective reaction to the consumption experience (e.g. Huang, Weiler, and Assaker 2015). Some studies (e.g. del Bosque and San Martin 2008; Žabkar, Brenčič, and Dmitrović 2010) adopt a cognitive-affective perspective when modelling tourist satisfaction. Irrespective of how satisfaction is conceptualized, a rich body of tourism research confirms a relationship between positive emotions and satisfaction (e.g. Bigné, Andreu and Gnoth 2005; del Bosque and San Martin 2008; 
Yuksel and Yuksel 2007). Positive emotions such as joy (Faullant, Matzler, and Mooradian 2011), happiness, excitement and pleasure (Grappi and Montanari 2011) have a favorable influence on satisfaction. Based on the above discussion, the following hypothesis is formulated:

$\mathbf{H}_{3}$ : Positive emotions have a positive effect on satisfaction

\section{Negative Emotions and Satisfaction}

Mixed evidence exists on the relationship between negative emotions and satisfaction. Previous research in marketing found a significant influence of negative emotions on satisfaction (e.g. Phillips and Baumgartner 2002; Westbrook 1987). Other studies establish that negative emotions have no effect on satisfaction (e.g. Westbrook and Oliver 1991). However, research in tourism confirms a negative relationship between negative emotions and satisfaction (del Bosque and San Martin 2008; Faullant, Matzler and Mooradian 2011; Grappi and Montanari 2011; Lee, Lee, Lee and Babin 2008). Hence, these findings lead to the following hypothesis:

$\mathbf{H}_{4}$ : Negative emotions have a negative effect on satisfaction

\section{The Relationship between Satisfaction and Place Attachment}

Consistent with the developmental theory of place attachment (Morgan, 2010), this study hypothesizes satisfaction as an antecedent of place attachment. Several studies support the satisfaction-place attachment link. For example, Su, Cheng and Huang (2011) reveal that tourist satisfaction affects both place identity and place dependence. Zenker and Rütter (2014) show that residents' overall satisfaction with a 
city significantly predicts attachment to the city. Lee, Kyle and Scott (2012), in the context of festivals, further establish a positive influence of satisfaction on both place identity and place dependence. In addition, some research in marketing models consumer satisfaction as an antecedent of brand attachment (Orth, Limon and Rose 2010). As such, it is logical to hypothesize:

$\mathbf{H}_{5}$ : Satisfaction has a positive effect on place attachment

\section{The Relationship between Place attachment and Intention to recommend}

Prior research shows empirical support for the effect of place attachment on various behavioral responses (Kil, Holland, Stein and Ko 2012). In nature-based recreation settings, for example, several studies (Halpenny 2010; Kil, Holland, Stein and Ko 2012; Ramkissoon, Smith and Weiler 2013; Tonge et al. 2015) identify a positive effect of place attachment on pro-environmental behaviors. In the context of festivals, Lee, Kyle and Scott (2012) show that place dependence predicts word-ofmouth. Attachment is also a significant determinant of willingness to promote a brand (Park et al. 2010). At the destination level, Prayag and Ryan (2012) establish that place identity and place dependence predict intention to recommend. Prayag and Ryan (2012) call for further research examining the relationship between place attachment and intention to recommend. Hence, the study proposes the following hypothesis:

$\mathbf{H}_{6}$ : Place attachment has a positive effect on intention to recommend

\section{The Relationship between Satisfaction and Intention to recommend}


Recommendation intentions are indicators of positive behavioral outcome from satisfactory tourist experiences (Bigné, Sanchez and Sanchez 2001; Grappi and Montanari 2011; Lee et al. 2008; Prayag and Ryan 2012). Satisfied tourists are more likely to recommend the destination to others (Bigné, Sanchez and Sanchez 2001; Chen and Tsai 2007). Dissatisfied tourists will engage in negative word-of-mouth (Prayag and Ryan 2012). Prior place attachment studies show that satisfaction has a positive influence on word-of-mouth ( $\mathrm{Su}$, Cheng and Huang 2011). Hence, these findings lead to the following hypothesis:

$\mathbf{H}_{7}$ : Satisfaction has a positive effect on intention to recommend

\section{Mediating Effects of Satisfaction and Place Attachment}

In investigating the relationship between emotions and intention to recommend, satisfaction is often operationalized as a key intervening construct (e.g. Bigné, Andreu and Gnoth 2005; Nyer 1997; Soscia 2007; Walsh et al. 2011). Nyer (1997) argues that word-of-mouth is best explained using both satisfaction and consumption emotions. Prior studies (e.g., Lee et al. 2008; Su and Hsu 2013; Yuksel and Yuksel 2007) support a direct effect of positive emotions on loyalty (including intention to recommend). Other research supports the role of satisfaction as a mediator between emotions and intention to recommend. For example, in the context of retailing, Walsh et al. (2011) found that satisfaction partially mediates the relationship between emotions and intention to recommend. Grappi and Montanari (2011) establish an indirect relationship between emotions (positive and negative) and repatronizing intentions via satisfaction. Based on the above discussions, the following hypothesis is formulated: 
$\mathbf{H}_{\mathbf{8 a}}$ : Satisfaction mediates the relationship between emotions (positive and negative) and intention to recommend

Existing research on place attachment tend to prioritize the direct effects of attachment on satisfaction (e.g. Lee, Kyle and Scott 2012; Prayag and Ryan 2012; Yuksel, Yuksel and Bilim 2010). Other studies examine either the indirect effects of attachment on behavioral intentions via satisfaction (Ramkissoon, Smith and Weiler 2013) or the mediating effects of behavioral intentions on the relationship between satisfaction and place attachment (Ramkissoon and Mavondo 2015). However, these studies examine the relationship between place attachment, satisfaction and behavioral intentions in the context of national parks and not tourist destinations More specifically, prior research fails to test the mediating effect of place attachment on the relationship between tourists' emotions and intention to recommend. Related studies (e.g., Orth, Limon and Rose 2010) on brand attachment show that satisfaction partially mediates the relationship between emotion and brand attachment. Hence, the study proposes:

$\mathbf{H}_{\mathbf{8 b}}$ : Place attachment mediates the relationship between emotions (positive and negative) and intention to recommend

\section{Methods}

\section{Measurement Scales}

The study main constructs were measured using multi-item scales. Positive emotions were captured using six items $(\alpha=0.88)$ adapted from Hosany and Gilbert's (2010) destination emotion scale (DES). Two items capture each of the DES three 
dimensions: joy, love and positive surprise. The six items were aggregated into the latent variable 'positive emotions'. Three items $(\alpha=0.85)$ : disappointment, displeasure and unhappiness, adapted from Hosany and Prayag (2013), measure negative emotions. Respondents had to rate the intensity of their emotional experience toward Thailand (e.g., "I felt a sense of pleasure"; "I felt a sense of disappointment") on a 7point scale ranging from [1] $=$ not at all and [7]=very much.

Place attachment was operationalized using eight items adapted from Williams and Vaske's (2003) scale. Several studies have confirmed the reliability and validity the scale in tourism (e.g., Gross and Brown 2008; Prayag and Ryan 2012; Yuksel, Yuksel and Bilim 2010). Place identity $(\alpha=0.89)$ and place dependence $(\alpha=0.88)$ were each measured using four statements. Respondents had to rate their level of agreement or disagreement with the statements on a 7-point scale (1=strongly disagree and $7=$ strongly agree). Satisfaction was operationalized as a summative overall construct $(\alpha=0.90)$ using the following statements (adapted from Faullant, Matzler and Mooradian 2011; Lee et al. 2008): "Please indicate your overall satisfaction with the destination experience" $[1=$ very dissatisfied and $7=$ very satisfied; and $1=$ terrible and $7=$ delighted]. Intention to recommend was measured using 3 statements $(\alpha=0.92)$ on a 7-point scale ( $1=$ strongly disagree and $7=$ strongly agree). The statements were adapted from previous studies (e.g. Lee et al. 2008; Žabkar, Brencic and Dmitrovic 2010).

To minimize any potential common method variance (CMV) bias, the survey design and administration follow Podsakoff, MacKenzie, Lee and Podsakoff's (2003) guidelines. In addition, Harman's single-factor test was employed to assess CMV (Podsakoff and Organ 1986). The test requires loading all the constructs in an exploratory factor analysis (EFA) procedure. CMV is present if either a single factor 
emerges from the data, or one general factor explains majority of the variance (Podsakoff et al. 2003). EFA results reveal the existence of a multi-factor structure (5 factors with eigenvalues greater than 1) with the first factor accounting for only $26 \%$ of the total variance (out of $73.10 \%$ ). EFA results suggest common method variance is not a pervasive issue in the data.

\section{Sampling and Data Collection}

Thailand is a South-East Asia's top tourist destination (World Tourism Organization, 2016). Around 30 million international tourists visited Thailand in 2015 (Thailand Department of Tourism 2016). A team of five trained research assistants collected data face-to-face with international tourists at the departure hall of the Suvarnabhumi International Airport in Bangkok. The airport was the most costeffective location to obtain a sample of international tourists. A purposive sampling procedure identified potential respondents. Only international tourists at the end of their stay in Thailand were invited to participate in the study. Potential respondents were approached at the departure hall's entrance. Similar to previous studies (e.g Hui, Wan and Ho 2007) and to minimize selection bias, departing international tourists were targeted at different times throughout the day (e.g. morning, afternoon and evening). If subjects did not qualify as international tourists, were in transit or were not willing to participate in the study, the research assistants intercepted the next available person. In total, 600 questionnaires were distributed and 570 respondents completed the survey. 53 cases were removed due to excessive missing data and a further 53 cases were identified as multivariate outliers (Mahalanobis $\mathrm{D}^{2}$ values with $\mathrm{p}$ values $\leq 0.001)$. A final total of 464 valid cases were retained for subsequent analyses. The sample was almost equally split between males and females Table 1). 
The majority of respondents (42.5\%) was in the age category $25-34$ years old and held a college degree (54.6\%). In terms of nationalities, two main groups were identified: Asia (44.8\%) and Europe (34.1\%). The sample had a high proportion of first time visitors to Thailand (40.3\%), and respondents travelled with a partner $(34.5 \%)$, friends $(33.6 \%)$, or alone $(24.6 \%)$.

[INSERT TABLE 1 HERE]

\section{Results}

\section{Measurement Model}

In terms of data distribution, skewness and kurtosis for the scale items were within the recommended absolute values, indicating no violation of the normality assumption (Kline 2005). To assess the psychometric properties of the scales, a fivefactor measurement model was estimated using AMOS. The model displayed satisfactory fit $\left(\chi^{2}=492.49, \chi^{2} / \mathrm{df}=2.53, \mathrm{CFI}=0.97, \mathrm{NFI}=0.95 ; \mathrm{RMSEA}=0.057\right)$. From Table 2, all factor loadings were greater than 0.644 and significant $(p<0.001)$ with $t$ values exceeding the critical value of 3.29 (Kline 2005). Place attachment was specified as a second-order construct, consisting of place identity (Std. $\beta=0.938$, $\mathrm{p}<0.001)$ and place dependence (Std. $\beta=0.941, \mathrm{p}<0.001)$. Composite reliabilities estimates were $\geq 0.90$, indicating that all the measures are reliable (Bagozzi and Yi 1988). Average variance extracted (AVE) for each construct was above 50\%, establishing the scales convergent validity (Fornell and Larcker 1981). Discriminant validity was examined by comparing the square root of AVE for each construct with the correlations between pairs of latent variables. For adequate discriminant validity, 
the diagonal elements in Table 3 should be greater than the off-diagonal elements (Fornell and Larcker 1981). Comparing all correlation coefficients with square roots of AVEs in Table 3, results suggest strong evidence of discriminant validity.

[INSERT TABLE 2 AND 3 HERE]

\section{Structural Model and Hypothesis Testing}

The hypothesized relationships were tested using structural equation modelling (SEM) and results are presented in Figure 1. Overall, the structural model achieves acceptable fit $\left(\chi^{2}=534.446, \mathrm{df}=197, \mathrm{p}<0.01, \chi^{2} / \mathrm{df}=2.713, \mathrm{CFI}=0.96\right.$, $\mathrm{NFI}=0.94, \mathrm{RMSEA}=0.061)$. Standardized estimates path coefficients establish a significant relationship between positive emotions and place attachment $(\beta=0.59$; $\mathrm{t}$ value $=12.26$ ). Contrary to theoretical predictions, negative emotions display a positive relationship with place attachment $(\beta=0.10 ; \mathrm{t}$-value $=2.76)$. The relationship between satisfaction and place attachment $\left(\mathrm{H}_{5}\right)$ is established $(\beta=0.41 ; \mathrm{t}$-value $=8.86)$. Together, tourists' emotions (positive and negative) and satisfaction explain a high proportion of variance in place attachment $\left(\mathrm{R}^{2}=0.713\right)$. Results also confirm the positive $\quad$ emotions $\rightarrow$ satisfaction $\quad(\beta=0.48 ; \quad t-v a l u e=10.39) \quad$ and negative emotions $\rightarrow$ satisfaction $(\beta=-0.28 ; \mathrm{t}$-value $=-6.28)$ relationships. Positive and negative emotions explain more than $38 \%$ of variance in satisfaction $\left(\mathrm{R}^{2}=0.389\right) . \mathrm{H}_{6}$, hypothesizing a relationship between place attachment and intention to recommend $(\beta=0.21 ; \mathrm{t}$-value $=3.89)$, is also supported. Finally, as theorized, the relationship satisfaction and intention to recommend is positive and significant $(\beta=0.60$; tvalue $=11.27$ ). Satisfaction and place attachment explains $58.1 \%$ of variance in intention to recommend. 


\section{[INSERT FIGURE 1 HERE]}

\section{Testing for Mediating Effects of Satisfaction and Place Attachment}

Mediation analyses establish whether the relationship between the independent variables (predictors) and the dependent variable is direct or indirect (Iacobucci, Saldanha and Deng 2007). Positive and negative emotions are modeled as predictors, with satisfaction and place attachment serving as mediating variables between emotions and intention to recommend. To test the mediating effect of place attachment and satisfaction, we first followed Baron and Kenny's (1986) general guidelines and test the significance of the indirect effects using Preacher and Hayes's (2008) bootstrap procedure. Four conditions are necessary to establish mediation effect (Baron and Kenny 1986). First, a direct link must be established between the independent and dependent variable. Second, the independent variable must be related to the mediating variable. Third, the mediator must be correlated with the dependent variable Fourth, the relationship between the independent variable and dependent variable must be reduced when controlling for the mediating variable. Complete mediation is established when the path coefficients for the independent variable in Condition 1 are significant and the same coefficients are not in Condition 4. Otherwise, assuming all the four conditions hold, partial mediation is supported (Baron and Kenny 1986).

Results provide support for the conditions necessary for mediation. The direct effects without the mediators show that positive emotions $(\beta=.495, p<.001)$ and negative emotions $(\beta=-.304, p<.001)$ were related to intention to recommend. Once the mediators are included in the model, findings indicate that (i) satisfaction $(\beta=$ 
$.196, p<.001)$ and place attachment $((\beta=.263, p<.001)$ partially mediates the relationship between positive emotions and intention to recommend $(\beta=.195, p<$ $.001)$; (ii) satisfaction $(\beta=-.169, p<.001)$ and place attachment $(\beta=-.176, p<.001)$ partially mediates the relationship between negative emotions and intention to recommend.

To assess whether the mediating effects are statistically significant, we follow Zhao, Lynch and Chen's (2010) guidelines. Preacher and Hayes's (2008) bootstrapping method with bias-corrected, 95\% confidence intervals and 5,000 iterations were used to test the significance of the indirect effects. If the indirect effect is significant and the confidence interval does not include zero, mediation is supported (Zhao, Lynch and Chen 2010). The bootstrap results (see Table 4) indicate that satisfaction significantly mediates the path of positive emotions $(\beta=.287, \mathrm{p}<.001$; $\mathrm{CI}=.226$ to .362$)$ and negative emotions $(\beta=-.139, \mathrm{p}<.001 ; \mathrm{CI}=-.201$ to -.088$)$ on intention to recommend. However, the indirect effect of positive emotions $(\beta=.011, p$ $=.821 ; \mathrm{CI}=-.076$ to .098$)$ and negative emotions $(\beta=.002, \mathrm{p}=.770 ; \mathrm{CI}=-.013$ to .018) on intention to recommend via place attachment is not significant. In summary, only satisfaction mediates the relationship between emotions and intention to recommend.

\section{[INSERT TABLE 4 HERE]}

\section{Discussions and Implications}

The main objective of this study was to test a conceptual framework examining the relationships between emotions (positive and negative), satisfaction, 
place attachment, and intention to recommend. Findings offer several theoretical and managerial implications. The proposed model builds on the developmental theory of place attachment (Morgan 2010). The theory suggests that place attachment develops as a result of multiple interactions with the environment, generating an individual bond with a place, informed by emotional associations such as pleasure, love, and grief. Although Morgan's (2010) theory was developed in the context of childhood experiences with place, our study found support for this theory in explaining tourists' attachment to destinations. According to our model, both positive and negative emotions are central to tourists' attachment to Thailand. From this perspective, tourists' onsite experiences create memories that evoke powerful emotions, which in turn influence behavior, consistent with Morgan's (2010) theory. Love and pleasure are emotions that imbue meaningful place-person interactions as recalled by participants in Morgan's (2010) study. Findings of this study show that the emotions of love and pleasure along with joy, amazement, caring and inspiration are central to meaningful tourism experiences. Such emotions contribute to place identity and place dependence consolidation, in line with the developmental theory of place attachment. Morgan's (2010) study suggests that the attachment figure can be a place or a person, which includes experiences in the natural environment as well as experiences that have occurred at 'home'. In the context of tourist destinations, the objects of attachment are multiple experiences are evaluated holistically.

Findings are consistent with the brand attachment literature, suggesting that high levels of felt positive emotions can lead to strong attachment (Park et al. 2010; Thompson, MacInnis and Park 2005). However, positive emotions that generate attachment for tourist destinations (e.g. amazement, love, and caring) are not necessarily similar to brand attachment studies in marketing (Thompson, MacInnis 
and Park 2005). Yet, some emotions such as love and pleasure seem central to all positive consumption experiences (Scannell and Gifford 2010). Beyond research in marketing, the study also contributes to the environmental psychology and geography literatures (Halpenny 2010) by explicitly showing that emotions are antecedents of place identity and place dependence rather than a sub-dimension of place attachment. Positive and negative emotions arousing from on-site experiences influence the extent to which a tourist identifies with a place. Findings, unlike prior studies only considering the effects of satisfaction on place attachment (e.g. Chen and Phou 2013; Su, Cheng and Huang 2011; Zenker and Rütter 2014), show the merits of including both emotions and satisfaction to explain place attachment.

Contrary to predictions, negative emotions make a positive contribution to place attachment. Tourists' negative emotional experiences do not mitigate their levels of attachment to the destination. A number of plausible reasons exist to explain these divergent results. First, consumer research indicates negative emotions can result from events that are relevant to but incongruent with consumption goals. Hence, consumers mitigate the importance of negative emotions in their evaluations of experiences (Lerner and Keltner 2001; Menon and Dube 2007). Second, when negative emotions occur, tourists evaluate how the destination contributes to selfidentity and the provision of features and conditions that support the achievement of specific goals or desired activities (Williams and Vaske 2003). Hence, low levels of negative emotions and high levels of place dependence or place identity can still lead to strong place attachment. It is worth mentioning that low levels of negative emotions in tourists recalled experiences reflect a positive bias, also known as the 'rosy view' phenomenon (Mitchell et al. 1997). The rosy view effect mitigates negative emotions in people's assessments of events and magnifies positive 
experiences (Gilbert et al. 1998; Lee and Kyle 2012). Although negative experiences reduce the enjoyment of the moment, these disappointments are fleeting (Mitchell et al. 1997) and people reinterpret their experiences in ways consistent with their original expectations (Klaaren, Hodges and Wilson 1994).

In line with prior studies (e.g. Faullant, Matzler and Mooradian 2011; Grappi and Montanari 2011) results show that positive emotions have a favorable influence on satisfaction. Findings also align with previous research in marketing (Phillips and Baumgartner 2002; Westbrook 1987) and tourism (del Bosque and San Martin 2008; Lee et al. 2008) suggesting that negative emotions attenuate satisfaction levels. In addition, results confirm satisfaction as an antecedent of place attachment, consistent with research in environmental psychology (Hernandez et al. 2007; Zenker and Rutter 2014), tourism (Chen and Phou 2013; Lee, Kyle and Scott 2012; Su, Cheng and Huang 2011) and marketing (Orth, Limon and Rose 2010).

Emotional experiences can potentially modify behavior by creating or strengthening brand attachment (Orth et al. 2012). This study confirms that emotions have an indirect influence on intention to recommend via both satisfaction and place attachment. In addition, results establish that satisfaction has a positive effect on intention to recommend as identified in previous tourism studies (Bigné, Andreu and Gnoth 2005; Grappi and Montanari 2011; Su, Cheng and Huang 2011). Satisfied tourists are more likely to recommend the destination to others. Similarly, in line with previous studies (e.g. Prayag and Ryan 2012), place attachment has a positive effect on intention to recommend. The more tourists feel attached, the higher their propensity to recommend a destination.

The mediating effects of satisfaction on both the relationship between positive and negative emotions and intention to recommend confirm prior studies identifying 
an indirect relationship between emotions and behavioral intentions via satisfaction (Grappi and Montanari 2011; Lee et al. 2008; Yuksel and Yuksel 2007). More specifically, results highlight the need to incorporate both emotions (positive and negative) and satisfaction in modeling tourists' intention to recommend. Contrary to expectations, results fail to support the mediating effects of place attachment on the relationship between tourists' emotions (positive and negative) and intention to recommend. A plausible explanation relates to the fact that tourists have higher propensity to recommend the destination, irrespective of the level of attachment. Table 2 confirms higher mean scores for the intention to recommend construct compared to place identity and place dependence. Overall, the mediation results suggest that satisfaction plays a more significant role in explaining intention to recommend and serves as a stronger transient factor than place attachment.

\section{Managerial Implications}

From a practical point of view, the results offer several implications for destination marketers. Findings show that positive emotions such as amazement, caring, inspiration joy, love, and pleasure determine both satisfaction and place attachment. Destination marketing organizations (DMOs) can develop advertising and communication campaigns about Thailand using these emotions as anchors. Thailand already utilizes 'Amazing Thailand' as tagline for the destination's brand. Results highlight opportunities to supplement this tag line with other emotive words such as 'inspiration' and 'love'. For example, 'Inspiring Food' can be used to market the distinctive cuisine of Thailand. Agapito, Mendes and Valle (2013) argue the need for destinations to design and market 'tastescapes', 'smellscapes' and 'soundscapes' for 
new product development and differentiation purposes. Thailand's DMOs can design and market 'tastescapes' and 'smellscapes' based on the country's rich culture and cuisine (e.g., floating flower and food markets), tapping into the sensorial elements of the tourist experience in order to generate positive emotions. In addition, the distinctive notes in Thai music through cultural shows can be used to enhance 'soundscapes' to elicit emotions.

Furthermore, results indicate emotions (positive and negative) influence satisfaction. For Thailand, managing tourism experiences is critical if marketers want tourists to recommend the destination to others. Tourists' positive and negative emotions emerge from service encounters. For example, negative emotions arising from failures with service providers such as hotels, tour operators and restaurants can be minimized through employee training and emotional labor management. In addition, tourists' interactions with residents during their holidays are a source of both positive and negative emotions. DMOs should put in place campaigns to educate residents and emphasize of importance of displaying desirable behaviors (e.g., friendliness, courtesy, and respect) in order to create positive place experiences among tourists.

Strengthening place attachment should be a priority for destination marketers. Findings of this study reveal that the antecedents of place attachment are emotions and satisfaction. As suggested in previous studies (e.g. Prayag and Ryan 2012; Su, Cheng and Huang 2011), strategies to develop place attachment include enhancing tourists' interactions with the physical settings (for example, improving interpretation of cultural activities at heritage sites and immersing tourists in the destination experience through cooking classes at hotels) and encouraging social interactions between tourists and residents. Such experiences create memories that reinforce 
emotions associated with a place (Grisaffe and Nguyen 2011). Moreover, strategies to increase place identity and place dependence include on-site marketing of activities (Ramkissoon, Smith and Weiler 2013) and the availability of apps allowing tourists to customize their experiences. For example, on-site marketing activities such as signups for loyalty programs, exclusive discounts on tours and activities, and upgrades on hotels and flights are ways to create place dependence.

There are limited tourism experiences that are devoid of negative emotions (Hosany and Prayag 2013). However, negative emotions though common, do not necessarily adversely impact evaluations of a holiday experience (Nawijn et al. 2013). While DMOs should aim to arouse positive emotions, negative emotions should be managed to prevent dissatisfaction without comprising place attachment. In addition, both positive and negative emotions influence overall satisfaction. Traditional strategies such as targeting, developing niche products for specific segments, and coordinating service providers are necessary to improve tourist satisfaction levels. However, improving tourist satisfaction cannot be isolated from strategies to enhance destination attachment given that both influence intention to recommend.

\section{Limitations and Directions for Future Research}

The results of this study should be interpreted with caution for a number of reasons. First, only conscious emotions were captured using self-reports. Retrospective evaluations of emotional responses can be problematic (Cutler, Larsen and Bruce 1996), given that they are vulnerable to memory reconstruction (Kahneman, Diener and Schwarz 1999). Future studies should attempt to capture unconscious or implicit emotional responses that can provide unbiased portrayal of 
individuals' initial emotional reactions when exposed to a stimulus ( $\mathrm{Li}$, Scott and Walters 2015). Second, satisfaction was operationalized at the global level and future studies could adopt an attribute-level conceptualization of satisfaction (e.g. Chi and Qu 2008; Eusébio and Vieira 2013). Third, based on the developmental theory of place attachment, this study hypothesizes satisfaction as antecedent of place attachment. Other studies (e.g. Prayag and Ryan 2012; Ramkissoon, Smith and Weiler 2013; Yuksel, Yuksel and Bilim 2010) conceptualize satisfaction as an outcome of place attachment. Additional research should test for competing models to further understand the place attachment-satisfaction relationship.

Fourth, researchers (e.g. Robinson 2012) challenge the notion that tourists merely seek pleasure or a state of joy. Future studies should test the model in the context of other tourist experiences such as dark tourism or travel to war sites. For example, in dark tourism experiences, negative emotions are consciously sought-after experiences. Such negative emotions promote positive future intentions (Nawijn and Fricke 2015). Furthermore, place attachment was conceptualized in terms of two common dimensions: place identity and place dependence (e.g. Gross and Brown 2008; Prayag and Ryan 2012; Williams and Vaske 2003). Future studies should incorporate other dimensions such as social bonding (Ramkissoon, Smith and Weiler 2013) and place memory (Chen, Dwyer and Firth 2014) in the measurement of place attachment. In addition, consistent with the dominant approach in tourism research (e.g. Tonge et al., 2015), in this study place attachment was measured post-visit. However, an individual might have developed an attachment to a place prior to travel (Kyle, Mowen and Tarrant 2004). An area for future research would be to capture pre and post-visit levels of place attachment using a longitudinal research design. 
Tourists to a destination comprise both first-timers and repeaters (Um, Chon and Ro 2006). Previous research have established that first-timers and repeaters differ in terms of socio-demographics, travel characteristics, destination perceptions, travel motivations, perceived value and post-trip evaluation (e.g. Fakeye and Crompton, 1991; Petrick, 2004; Li et al., 2008; Choo and Petrick, 2016). Additional research should test the proposed model using multi-group analysis to compare first-timers versus repeaters. However, a recent study by Cheng and Kuo (2015) suggest individuals can develop bonds to places never visited before. Hence, a distinction between first-time and repeat visitors, though useful, may be futile in understanding place attachment. Finally, collecting data at a large international airport is an ideal spot to survey tourists but such a high-security location places certain restrictions on fieldwork. The convenience sampling approach and cross-sectional data used in this study restrict generalization. Future studies should perhaps consider a more sophisticated sampling procedure (e.g. stratified or quota). 


\section{References}

Agapito, D., J. Mendes, and P. Valle. 2013. "Exploring the Conceptualization of the Sensory Dimension of Tourist Experiences.” Journal of Destination Marketing \& Management 2(2): 62-73.

Ahuvia, A.C. 2005. 'Beyond the Extended Self: Loved Objects and Consumers' Identity Narratives.” Journal of Consumer Research 32(1): 171-184.

Altman I., and S. Low.1992. (Eds.). Place Attachment, Human Behaviour and Environment: Advances in Theory and Research. New York: Plenum Press.

Bagozzi, R. P., and Y. Yi. 1988. "On the Evaluation of Structural Equation Models.” Journal of the Academy of Marketing Science 16(1): 74-94.

Baron, R.M., and D.A. Kenny. 1986. “The Moderator-Mediator Variable Distinction in Social Psychological Research: Conceptual, Strategic, and Statistical Considerations." Journal of Personality and Social Psychology 51(6): 11731182.

Bennett, J. A. 2000. "Mediator and Moderator Variables in Nursing Research: Conceptual and Statistical Differences." Research in Nursing and Health 23(5): 415-420.

Bigné, J.E., L. Andreu, and J. Gnoth, 2005. "The Theme Park Experience: An Analysis of Pleasure, Arousal and Satisfaction." Tourism Management 26(6): 833-844.

Bigné, J.E., M.I. Sanchez, and J. Sanchez. 2001. “Tourism Image, Evaluation Variables and After Purchase Behaviour: Inter-Relationship." Tourism Management 22(6): 607-616.

Bowlby, J. 1982. “Attachment and Loss: Retrospect and Prospect.” American Journal of Orthopsychiatry 52(4): 664-678. 
Chen, C. F., and S. Phou. 2013. “A Closer Look at Destination: Image, Personality, Relationship and Loyalty." Tourism Management 36: 269-278.

Chen, C.F., and D. Tsai. 2007. "How Destination Image and Evaluative Factors Affect Behavioral Intentions?” Tourism Management 28(4): 1115-1122.

Chen, N.C., L. Dwyer, and T. Firth. 2014. Conceptualization and Measurement of Dimensionality of Place Attachment.” Tourism Analysis 19(3): 323-338.

Cheng, C. K., and H.Y. Kuo. 2015. "Bonding to a New Place never Visited: Exploring the Relationship between Landscape Elements and Place Bonding.” Tourism Management 46: 546-560.

Cheng, T.M., C. H. Wu, and L.M. Huang. 2013. "The Influence of Place Attachment on the Relationship between Destination Attractiveness and Environmentally Responsible Behavior for Island Tourism in Penghu, Taiwan.” Journal of Sustainable Tourism 21(8): 1166-1187.

Choo, H. and J.F. Petrick. 2016. "Understanding the Role of Social Influences In Festival Revisiting Intentions: Comparison Between First-timers and Repeaters." Tourism Analysis 21(2/3): 279-285

Cohen, J.B., and C. Areni. 1991. Affect and Consumer Behavior. In : S. T. Robertson and H. H. Kassarjian (Eds.) Handbook of Consumer Behavior. Englewood Cliffs, NJ : Prentice Hall: 188-240.

Cutler, S.E., R.J. Larsen, and S.C. Bruce. 1996. "Repressive Coping Style and the Experience and Recall of Emotion: A Naturalistic Study of Daily Affect." Journal of Personality 64(2): 379-405.

del Bosque, I.R., and H. San Martin. 2008. "Tourist Satisfaction: A CognitiveAffective Model." Annals of Tourism Research 35(2): 551-573. 
Eusébio, C., and A.L. Vieira, 2013. 'Destination Attributes' Evaluation, Satisfaction and Behavioural Intentions: A Structural Modelling Approach.” International Journal of Tourism Research 15(1): 66-80.

Fakeye, P.C. and J.L. Crompton. 1991. "Image Differences between Prospective, First-time, and Repeat Visitors to the Lower Rio Grande Valley.” Journal of Travel Research 30(2): 10-16

Faullant, R., K. Matzler, and T.A. Mooradian. 2011. "Personality, Basic Emotions, and Satisfaction: Primary Emotions in the Mountaineering Experience." Tourism Management 32(6): 1423-1430.

Fornell, C., and D. F. Larcker (1981). "Evaluating Structural Equation Models with Unobservable Variables and Measurement Error.”Journal of Marketing Research, 18(1): 39-50.

Gardner, M.P. 1985. "Mood States and Consumer Behavior: A Critical Review." Journal of Consumer Research 12(3): 281-300

Gilbert, D.T., E.C. Pinel, T.D Wilson, S.J. Blumberg and T.P. Wheatley. 1998. "Immune Neglect: A Source of Durability Bias in Affective Forecasting." Journal of Personality and Social Psychology, 75(3): 617-638

Grappi, S., and F. Montanari. 2011. "The Role of Social Identification and Hedonism in Affecting Tourist Re-Patronizing Behaviors: The Case of an Italian festival." Tourism Management 32: 1128-1140.

Grisaffe, D.B., and H.P. Nguyen (2011). “Antecedents of Emotional Attachment to Brands." Journal of Business Research 64(10): 1052-1059.

Gross, M.J., and G. Brown. 2008. “An Empirical Structure Model of Tourists and Places: Progressing Involvement and Place Attachment into Tourism.” Tourism Management 29(6): 1141-1151. 
Halpenny, E.A. 2010. "Pro-Environmental Behaviours and Park Visitors: The Effect of Place Attachment.” Journal of Environmental Psychology 30(4): 409-421.

Hernández, B., M.C. Hidalgo, M.E., Salazar-Laplace, and S. Hess. 2007. "Place Attachment and Place Identity in Natives and Non-Natives." Journal of Environmental Psychology 27(4): 310-319.

Hou, J.S., C. H. Lin, and D.B. Morais. 2005. “Antecedents of Attachment to a Cultural Tourism Destination: The Case of Hakka and Non-Hakka Taiwanese Visitors to Pei-Pu, Taiwan.” Journal of Travel Research 44(2): 221-233.

Hosany, S., and D. Gilbert 2010. 'Measuring Tourists' Emotional Experiences toward Hedonic Holiday Destinations.” Journal of Travel Research 49(4): 513-526.

Hosany, S., and G. Prayag. 2013. 'Patterns of Tourists' Emotional Responses, Satisfaction, and Intention to Recommend." Journal of Business Research 66(6): 730-737.

Hosany, S., G. Prayag, S. Deesilatham, S. Cauševic, and K. Odeh. 2015. "Measuring Tourists' Emotional Experiences: Further Validation of the Destination Emotion Scale." Journal of Travel Research 54(4): 482-495.

Huang, S., B. Weiler, and G. Assaker. 2015. "Effects of Interpretive Guiding Outcomes on Tourist Satisfaction and Behavioral Intention.” Journal of Travel Research 54(3): 344-358

Hui, T.K., D. Wan, and A. Ho. 2007. “Tourists' Satisfaction, Recommendation and Revisiting Singapore.” Tourism Management 28(4): 965-975.

Hwang, S.N., C. Lee, and H.J. Chen. 2005. “The Relationship among Tourists” Involvement, Place Attachment and Interpretation Satisfaction in Taiwan's National Parks.” Tourism Management 26(2): 143-156. 
Iacobucci, D., N. Saldanha, and X. Deng. 2007. “A meditation on Mediation:

Evidence that Structural Equations Models Perform better than Regressions.” Journal of Consumer Psychology 17(2): 139-153.

Izard, E.E. 1977. Human Emotions. New York: Plenum Press.

Jorgensen, B.S., and R.C. Stedman. 2001. "Sense of Place as an Attitude: Lakeshore Owners Attitudes toward their Properties." Journal of Environmental Psychology 21(3): 233-248.

Kahneman, D., E. Diener, and N. Schwarz (Eds.). 1999. Well-being: Foundations of Hedonic Psychology. Russell Sage Foundation.

Kil, N., S.M. Holland, T.V. Stein, and Y.J. Ko. 2012. "Place Attachment as a Mediator of the Relationship between Nature-Based Recreation Benefits and Future Visit Intentions.” Journal of Sustainable Tourism 20(4): 603-626.

Kline, R.B. 2005. Principles and Practice of Structural Equation Modeling (2 ${ }^{\text {nd }}$ ed.).

New York: The

Guilford Press.

Klaaren, K.J., S.D. Hodges, and T.D. Wilson. 1994. "The Role of Affective

Expectations in Subjective Experience and Decision-Making." Social Cognition, 12(2): 77-101

Knobloch, U., K.Robertson, and R.Aitken. 2016. "Experience, Emotion, and Eudaimonia: A Consideration of Tourist Experiences and Well-being.” Journal of Travel Research (in press): 1-12

Kyle, T.G., A.J. Mowen, and M. Tarrant. 2004. "Linking Place Preferences with Place Meaning: An Examination of the Relationship between Place Motivation and Place Attachment." Journal of Environmental Psychology 24(4): 439-454. 
Laros, F.J. M. and J-B. E. M. Steenkamp (2005). "Emotions in Consumer Behavior: A Hierarchical Approach.” Journal of Business Research 58(10): 1437-1445. Lazarus, R.S. 1991. Emotion and Adaptation. New York: Oxford University Press. Lee, J., and G.T. Kyle. 2012. "Recollection Consistency of Festival Consumption Emotions." Journal of Travel Research 51(2): 178-190.

Lee, J. J., and G.T. Kyle. 2013. “The Measurement of Emotions Elicited within Festival Contexts: A Psychometric Test of a Festival Consumption Emotions (FCE) Scale.” Tourism Analysis 18(6): 635-649.

Lee, J.J., G.T. Kyle, and D. Scott. 2012. "The Mediating Effect of Place attachment on the Relationship between Festival Satisfaction and Loyalty to the Festival Hosting Destination.” Journal of Travel Research 51(6): 754-767

Lee, Y.K., C. Lee, S. Lee, and B.J. Babin. 2008. 'Festivalscapes and Patrons' Emotions, Satisfaction and Loyalty." Journal of Business Research 61(1): 5664.

Lerner, J. S., and D. Keltner. 2001. "Fear, Anger, and Risk.” Journal of Personality and Social Psychology 81(1): 146-159.

Lewicka, M. 2011. "Place Attachment: How Far have we come in the Last 40 Years?” Journal of Environmental Psychology 31(3): 207-230.

Li, S., N. Scott, and G. Walters. 2015. "Current and Potential Methods for Measuring Emotion in Tourism Experiences: A review." Current Issues in Tourism 18(9): 805-827.

Li, X., C-K Cheng, H. Kim and J.F. Petrick. 2008. “A Systematic Comparison of First-time and Repeat Visitors via a Two-phase Online Survey.” Tourism Management 29(2): 278-293 
Lin, Y., D. Kerstetter, J. Nawijn, and O. Mitas. 2014. "Changes in Emotions and their Interactions with Personality in a Vacation Context." Tourism Management 40: 416-424.

Low, S.M, and I. Altman. 1992. Place attachment - A conceptual inquiry. In I. Altman and S. Low (Eds.). Place Attachment, Human Behaviour and Environment: Advances in Theory and Research. New York: Plenum Press.

Manzo, L. C. 2003. "Beyond House and Haven: Toward a Revisioning of Emotional Relationships with Places.” Journal of Environmental Psychology 23(1): 4761.

Manzo, L.C. 2005. "For Better or Worse: Exploring Multiple Dimensions of Place Meaning." Journal of Environmental Psychology 25(1): 67-86.

Mehrabian, A. and J.A. Russell. 1974. An Approach to Environmental Psychology. Cambridge, MA: MIT Press.

Menon, K., and L. Dubé. 2007. “The Effect of Emotional Provider Support on Angry versus Anxious Consumers." International Journal of Research in Marketing 24(3): $268-275$.

Mitchell, T.R., L. Thompson, E. Peterson, and R. Cronk. 1997. “Temporal Adjustments in the Evaluation of Events: The "Rosy View." Journal of Experimental Social Psychology 33: 421-448.

Moore, R. L., and A.R. Graefe. 1994. "Attachments to Recreation Settings: The Case of Rail-Trail Users.” Leisure Sciences 16(1): 17-31.

Morgan, P. 2010. “Towards a Developmental Theory of Place Attachment.” Journal of Environmental Psychology 30(1): 11-22. 
Mugge, R., H.N.J. Schifferstein, and J.P.L. Schoormans. 2010. "Product Attachment and Satisfaction: Understanding Consumers' Post-Purchase Behavior.” Journal of Consumer Marketing 27(3): 271-282.

Nawjin, J. 2011. “Determinants of Daily Happiness on Vacation.” Journal of Travel Research 50(5): 559-566.

Nawijn, J., and M.C. Fricke. 2015. "Visitor Emotions and Behavioral Intentions: The Case of Concentration Camp Memorial Neuengamme.” International Journal of Tourism Research 17(3): 221-228.

Nawijn, J., O. Mitas, Y. Lin, and D. Kerstetter. 2013. "How do we Feel on Vacation? A Closer Look at how Emotions Change over the Course of a Trip." Journal of Travel Research 52(2): 265-274.

Nyer, P. U. 1997. “A Study of the Relationships between Cognitive Appraisals and Consumption Emotions.” Journal of the Academy of Marketing Science 25(4): 296-304.

Oliver, R.L. 1997. Satisfaction: A Behavioral Perspective on the Consumer. New York: McGraw-Hill.

Orth, U.R., Y. Limon, and G. Rose. 2010. "Store-Evoked Affect, Personalities and Consumer Emotional Attachments to Brands.” Journal of Business Research 63(11): 1202-1208.

Orth, U.R., A. Stock1, R. Veale, J. Brouard, A. Cavicchi, M. Faraoni, M. Larreina, B. Lecat, J. Olsen, C. Rodriguez-Santos, C. Santini, and D. Wilson. 2012. “Using Attribution Theory to Explain Tourists' Attachments to Place-Based Brands." Journal of Business Research 65(9): 1321-1327.

Otto, J.E., B.R. Ritchie. 1996. “The Service Experience in Tourism.” Tourism Management 17(3): 165-174 
Park, W.C., D.J. MacInnis, J. Priester, A.B. Eisingerich, and D. Iacobucci. 2010.

"Brand Attachment and Brand Attitude Strength: Conceptual and Empirical Differentiation of Two Critical Brand Equity Drivers.” Journal of Marketing 74(6): 1-17.

Petrick, J.F. 2004. “First timers' and Repeaters Perceived Value.” Journal of Travel Research 43(1): 29-38

Phillips, D. M., and H. Baumgartner. 2002. "The Role of Consumption Emotions in the Satisfaction Response." Journal of Consumer Psychology 12(3): 243-252.

Plutchik, R. 1980. Emotion: A Psychoevolutionary Synthesis. New York, NY: Harper \& Row.

Podsakoff, P.M., and D.W. Organ. 1986. "Self-Reports in Organizational Research: Problems and Prospects.” Journal of Management 12(4): 531-544.

Podsakoff, P.M., S.M. MacKenzie, J. Lee, and N.P. Podsakoff. 2003. "Common Method Variance in Behavioral Research: A Critical Review of the Literature and Recommended Remedies." Journal of Applied Psychology 88(5): 879903.

Poria, Y., A. Reichel, and A. Biran. 2006. "Heritage Site Management: Motivations and Expectations." Annals of Tourism Research 33(1): 162-178.

Prayag, G., and C. Ryan. 2012. “Antecedents of Tourists’ Loyalty to Mauritius: The Role and Influence of Destination image, Place attachment, Personal involvement and Satisfaction." Journal of Travel Research 51(3): 342-356.

Prayag, G., S. Hosany, and K. Odeh. 2013. “The Role of Tourists' Emotional Experiences and Satisfaction in Understanding Behavioral Intentions." Journal of Destination Marketing \& Management 2(2): 118-127. 
Preacher, K. J., and A. F. Hayes. 2008. “Asymptotic and Resampling Strategies for Assessing and Comparing Indirect Effects in Multiple Mediator Models." Behavior Research Methods 40(3): 879-891.

Ramkissoon, H., and F.T. Mavondo. 2015. "The Satisfaction-Place Attachment Relationship: Potential Mediators and Moderators. Journal of Business Research 68(12): 2593-2602.

Ramkissoon, H., L.D G. Smith, and B. Weiler. 2013. "Testing the Dimensionality of Place Attachment and its Relationships with Place Satisfaction and ProEnvironmental Behaviours: A Structural Equation Modelling Approach.” Tourism Management 36: 552-566.

Relph, E. 1985. "Geographical Experiences and Being-in-the-World: The Phenomenological Origins of Geography." In Dwelling, Place and Environment (pp. 15-31). Springer Netherlands.

Relph, E. 1976. Place and Placelessness. London: Pion.

Robinson, M. 2012. “The Emotional Tourist.” In Emotion in Motion: Tourism, Affect and Transformation, edited by D. Picard and M. Robinson, 21-45. Burlington, VT: Ashgate

Russell, J.A. 1980. “A Circumplex Model of Affect.” Journal of Personality and Social Psychology 39(6): 1161-1178.

Scannell, L. and R. Gifford. 2010. "Defining Place Attachment: A Tripartite Organizing Framework." Journal of Environmental Psychology 30(1): 1-10.

Schoefer, K., and A. Diamantopoulos. "Measuring Experienced Emotions During Service Recovery Encounters: Construction and Assessment of the ESRE Scale.” Service Business 2(1): 65-81 
Soscia, I. 2007. 'Gratitude, Delight, or Guilt: The Role of Consumers' Emotions in Predicting Post-Consumption Behaviors.” Psychology \& Marketing 24(10): 871-894.

Su, H. J., K. F. Cheng, and H.H. Huang. 2011. "Empirical Study of Destination Loyalty and its Antecedent: The Perspective of Place Attachment." The Service Industries Journal 31(16): 2721-2739.

Su, L., and M.K. Hsu. 2013. "Service Fairness, Consumption Emotions, Satisfaction, and Behavioral Intentions: The Experience of Chinese Heritage Tourists." Journal of Travel \& Tourism Marketing 30(8): 786-805.

Thailand Department of Tourism (2016). "International Tourist Arrivals to Thailand in 2015". Report available at:

http://www.tourism.go.th/home/details/11/221/24710 [accessed on 22 September 2016]

Thomson, M., D.J. MacInnis, and W.C. Park. 2005. "The Ties that Bind: Measuring the Strength of Consumers' Attachment to Brands." Journal of Consumer Psychology 15(1): 77-91.

Tonge, J., M.M. Ryan, S.A. Moore, and L.E. Beckley. 2015. “The Effect of Place Attachment on Pro-environment Behavioral Intentions of Visitors to Coastal Natural Area Tourist Destinations.” Journal of Travel Research 54(6): 730743.

Trentelman, C. K. 2009. "Place Attachment and Community Attachment: A Primer Grounded in the Lived Experience of a Community Sociologist." Society and Natural Resources 22(3): 191-210.

Tuan, Y.F. 1980. “Rootedness versus Sense of Place.” Landscape 24: 3-8. 
Um, S., K. Chon and Y-H. 2006. “Antecedents of Revisit Intention.” Annals of Tourism Research 33(4): 1141-1158

Veasna, S., W.Y. Wu, and C.H. Huang. 2013. "The Impact of Destination Source Credibility on Destination Satisfaction: The Mediating Effects of Destination Attachment and Destination Image.” Tourism Management 36: 511-526.

Vlachos, P.A., A. Theotokis, K. Pramatari, and A. Vrechopoulos .2010. "ConsumerRetailer Emotional Attachment: Some Antecedents and the Moderating Role of Attachment Anxiety." European Journal of Marketing 44(9/10): 14781499.

Walsh, G., E. Shiu, L.M. Hassan, N. Michaelidou, and S.E. Beatty. 2011. "Emotions, Store-Environmental Cues, Store-Choice Criteria, and Marketing Outcomes." Journal of Business Research 64(7): 737-744.

Watson, D., L.A. Clark, and A. Tellegen.1988. "Development and Validation of Brief Measures of Positive and Negative Affect: The PANAS Scales.” Journal of Personality and Social Psychology 54(6): 1063-1070.

Westbrook, R. A. 1987. "Product/Consumption-Based Affective Responses and Postpurchase Processes." Journal of Marketing Research 24(8): 258-270.

Westbrook, R. A., and R. L. Oliver. 1991. "The Dimensionality of Consumption Emotion Patterns and Consumer Satisfaction." Journal of Consumer Research 18(1): 84-91.

Williams, D.R., and J.J. Vaske. 2003. "The Measurement of Place Attachment: Validity and Generalizability of a Psychometric Approach." Forest Science 49(6): 830-840. 
World Tourism Organization. (2016). “UNWTO Tourism Highlights 2016 Edition.” Report available online at: www.e-unwto.org/doi/pdf/10.18111/9789284418145 [accessed on 22 September 2016]

Wu, A. D., and B. D. Zumbo. 2008. "Understanding and Using Mediators and Moderators." Social Indicator Research 87(3): 367-392.

Yüksel, A., and F. Yüksel. 2007. "Shopping Risk Perceptions: Effects on Tourists' Emotions, Satisfaction and Expressed Loyalty Intentions.” Tourism Management 28(3): 703-713.

Yuksel, A., F. Yuksel, and Y. Bilim. 2010. "Destination Attachment: Effects on Consumer Satisfaction and Cognitive, Affective and Conative Loyalty." Tourism Management 31(2): 274-284.

Žabkar, V., M. M. Brenčič, and T. Dmitrović. 2010. "Modelling Perceived Quality, Visitor Satisfaction and Behavioural Intentions at the Destination Level.” Tourism Management 31(4): 537-546.

Zhao, X., J.G. Lynch, and Q. Chen. 2010. "Reconsidering Baron and Kenny: Myths and Truths about Mediation Analysis." Journal of Consumer Research 37(2): 197-206.

Zenker, S., and N. Rütter. 2014. "Is Satisfaction the Key? The Role of Citizen Satisfaction, Place Attachment and Place Brand Attitude on Positive Citizenship Behavior." Cities 38: 11-17. 
Figure 1. The Structural Model

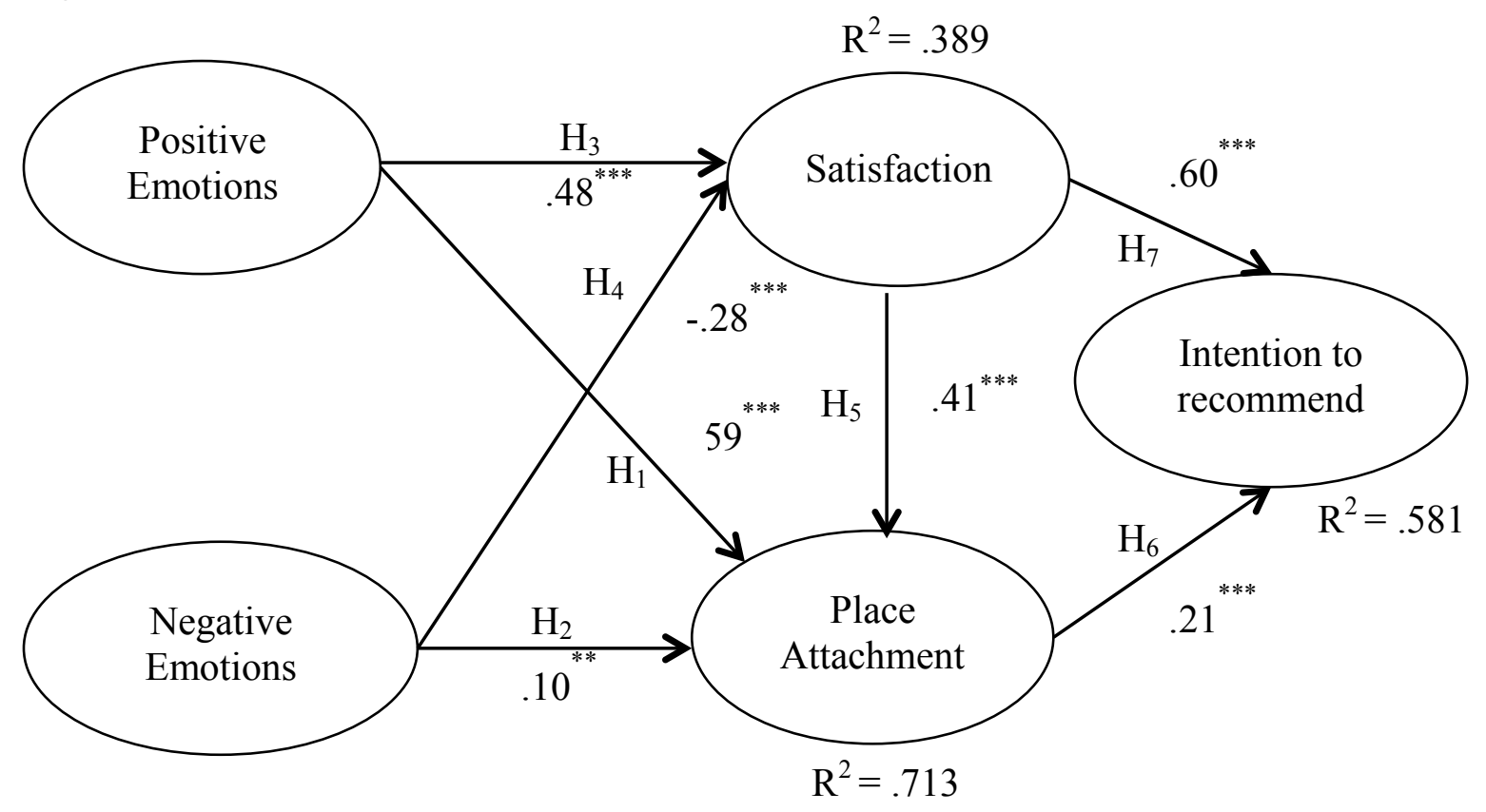

Note: $* * * p<.001,{ }^{* *} p<.01, \mathrm{n}=464 ; \chi 2=534.446, d f=197, \mathrm{p}<0.01, \chi 2 / d f=2.713$, $\mathrm{CFI}=0.96, \mathrm{NFI}=0.94, \mathrm{RMSEA}=0.061$ 
Table 1. Profile of Respondents and Travel Characteristics

\begin{tabular}{|c|c|c|c|c|c|}
\hline & $\begin{array}{r}\text { Frequency } \\
(\mathrm{N}=464)\end{array}$ & Percentage & & $\begin{array}{r}\text { Frequency } \\
(\mathrm{N}=464)\end{array}$ & Percentage \\
\hline Gender & & & Number of Previous Visits & & \\
\hline Male & 235 & 50.6 & No previous visit & 187 & 40.3 \\
\hline \multirow[t]{2}{*}{ Female } & 229 & 49.4 & $1-2$ times & 141 & 30.4 \\
\hline & & & More than 2 times & 132 & 28.5 \\
\hline Age & & & Missing & 4 & .9 \\
\hline $16-24$ & 83 & 17.9 & & & \\
\hline $25-34$ & 197 & 42.5 & Travel Companion & & \\
\hline $35-44$ & 90 & 19.4 & Alone & 114 & 24.6 \\
\hline $45-54$ & 44 & 9.5 & Partner & 160 & 34.5 \\
\hline $55-64$ & 39 & 8.4 & Friends & 156 & 33.6 \\
\hline 65 and above & 7 & 1.5 & Organized tour & 16 & 3.4 \\
\hline \multirow[t]{2}{*}{ Missing } & 4 & .9 & Other & 17 & 3.7 \\
\hline & & & Missing & 1 & .2 \\
\hline \multicolumn{6}{|c|}{ Highest Education Level Attained } \\
\hline Doctoral Degree & 20 & 4.3 & Length of Stay & & \\
\hline Postgraduate Degree & 69 & 14.9 & $1-5$ days & 104 & 22.4 \\
\hline College Graduate & 252 & 54.3 & $6-10$ days & 116 & 25 \\
\hline High School & 55 & 11.9 & 11-15 days & 53 & 11.4 \\
\hline Professional & 58 & 12.5 & 16-20 days & 42 & 9.4 \\
\hline Qualification & & & More than 20 days & 77 & 16.6 \\
\hline Others & 7 & 1.5 & Missing & 72 & 15.5 \\
\hline Missing & 3 & .6 & & & \\
\hline \multicolumn{6}{|l|}{ Nationality } \\
\hline Europe & 158 & 34.1 & & & \\
\hline America & 35 & 7.5 & & & \\
\hline Asia & 208 & 44.8 & & & \\
\hline Africa \& Middle & 20 & 4.3 & & & \\
\hline \multicolumn{6}{|l|}{ East } \\
\hline Others & 42 & 9.1 & & & \\
\hline Missing & 1 & .2 & & & \\
\hline
\end{tabular}


Table 2. Assessment of the Measurement Model: Reliability, Convergent and Discriminant Validity

\begin{tabular}{|c|c|c|c|c|c|c|}
\hline Construct and items & Mean & $\begin{array}{c}\text { Std. } \\
\text { Deviation }\end{array}$ & $\begin{array}{l}\text { Std. } \\
\text { Factor } \\
\text { Loading }\end{array}$ & $t$-values & $\begin{array}{l}\text { Construct } \\
\text { Reliability }\end{array}$ & $\begin{array}{l}\text { Average } \\
\text { variance } \\
\text { extracted }\end{array}$ \\
\hline Positive Emotions & & & & & .90 & .60 \\
\hline $\begin{array}{l}\text { PE1: I feel a sense of } \\
\text { Amazement }\end{array}$ & 5.54 & 1.25 & .896 & N/A & & \\
\hline PE2: I feel a sense of Caring & 5.36 & 1.35 & .873 & 26.78 & & \\
\hline $\begin{array}{l}\text { PE3: I feel a sense of } \\
\text { Inspiration }\end{array}$ & 4.93 & 1.49 & .852 & 25.53 & & \\
\hline PE4: I feel a sense of Joy & 5.64 & 1.24 & .693 & 17.79 & & \\
\hline PE5: I feel a sense of Love & 5.46 & 1.35 & .662 & 16.64 & & \\
\hline $\begin{array}{l}\text { PE6: I feel a sense of } \\
\text { Pleasure }\end{array}$ & 5.64 & 1.17 & .644 & 15.98 & & \\
\hline Negative Emotions & & & & & .90 & .74 \\
\hline $\begin{array}{l}\text { NE1: I feel a sense of } \\
\text { Disappointment }\end{array}$ & 1.58 & 1.09 & .947 & $\mathrm{~N} / \mathrm{A}$ & & \\
\hline $\begin{array}{l}\text { NE2: I feel a sense of } \\
\text { Displeasure }\end{array}$ & 1.51 & .98 & .877 & 26.29 & & \\
\hline $\begin{array}{l}\text { NE3: I feel a sense of } \\
\text { Unhappiness }\end{array}$ & 1.39 & .90 & .751 & 20.40 & & \\
\hline $\begin{array}{l}\text { Place Attachment (Second- } \\
\text { order Construct) }\end{array}$ & & & & & .94 & .88 \\
\hline Place Identity & & & .938 & 19.57 & .90 & .70 \\
\hline $\begin{array}{l}\text { PI1: Holidaying in Thailand } \\
\text { means a lot to me }\end{array}$ & 5.71 & 1.14 & .917 & N/A & & \\
\hline $\begin{array}{l}\text { PI2: Thailand is a very } \\
\text { special destination to me }\end{array}$ & 5.44 & 1.31 & .882 & 28.68 & & \\
\hline $\begin{array}{l}\text { PI3: I feel very attached to } \\
\text { Thailand }\end{array}$ & 5.33 & 1.39 & .833 & 25.32 & & \\
\hline $\begin{array}{l}\text { PI4: I identify strongly with } \\
\text { Thailand as a holiday } \\
\text { destination }\end{array}$ & 5.06 & .54 & .705 & 18.55 & & \\
\hline Place Dependence & & & .941 & N/A & .89 & .66 \\
\hline $\begin{array}{l}\text { PD1: Thailand is the best for } \\
\text { what I like to do on holidays }\end{array}$ & 5.24 & 1.42 & .847 & N/A & & \\
\hline $\begin{array}{l}\text { PD2: I would not substitute } \\
\text { Thailand with any other } \\
\text { place for the types of things } \\
\text { that I did during my holidays }\end{array}$ & 4.86 & 1.62 & .808 & 20.47 & & \\
\hline $\begin{array}{l}\text { PD3: Holidaying in Thailand } \\
\text { is more important than } \\
\text { holidaying in other places }\end{array}$ & 4.95 & 1.62 & .803 & 20.30 & & \\
\hline $\begin{array}{l}\text { PD4: I got more satisfaction } \\
\text { out of holidaying in Thailand } \\
\text { than from visiting other } \\
\text { similar places }\end{array}$ & 4.95 & 1.51 & .795 & 20.07 & & \\
\hline Satisfaction & & & & & .93 & .87 \\
\hline SA1: Very Dissatisfied - & 6.26 & .85 & .947 & N/A & & \\
\hline
\end{tabular}




\begin{tabular}{|c|c|c|c|c|c|c|}
\hline $\begin{array}{l}\text { Very Satisfied } \\
\text { SA2: Terrible-Delighted }\end{array}$ & 6.20 & .91 & .919 & 31.02 & & \\
\hline Intention to Recommend & & & & & .94 & .85 \\
\hline $\begin{array}{l}\text { BI1: I will recommend } \\
\text { Thailand to other people }\end{array}$ & 6.21 & 1.04 & .939 & N/A & & \\
\hline $\begin{array}{l}\text { BI2: I will say positive things } \\
\text { about Thailand to other } \\
\text { people }\end{array}$ & 6.17 & 1.08 & .912 & 34.41 & & \\
\hline $\begin{array}{l}\text { BI3: I will encourage friends } \\
\text { and relatives to visit Thailand }\end{array}$ & 6.23 & 1.06 & .909 & 34.08 & & \\
\hline
\end{tabular}

Note: ${ }^{a}$ All items measured on a 7-point scale; $\chi 2=492.49, d f=195, \mathrm{p}<0.01, \chi 2 / d f=2.53, \mathrm{CFI}=$ $0.97, \mathrm{NFI}=0.95 ; \mathrm{RMSEA}=0.057$ 
Table 3. Inter-construct Correlations

\begin{tabular}{|c|c|c|c|c|c|}
\hline & $\begin{array}{l}\text { Positive } \\
\text { Emotions }\end{array}$ & $\begin{array}{l}\text { Negative } \\
\text { Emotions }\end{array}$ & $\begin{array}{c}\text { Place } \\
\text { Attachment }\end{array}$ & Satisfaction & $\begin{array}{l}\text { Intention to } \\
\text { recommend }\end{array}$ \\
\hline Positive & .72 & & & & \\
\hline Emotions & & & & & \\
\hline $\begin{array}{l}\text { Negative } \\
\text { Emotions }\end{array}$ & -.34 & .86 & & & \\
\hline $\begin{array}{l}\text { Place } \\
\text { Attachment }\end{array}$ & .78 & -.26 & .94 & & \\
\hline Satisfaction & .56 & -.42 & .69 & .93 & \\
\hline $\begin{array}{l}\text { Intention to } \\
\text { recommend }\end{array}$ & .60 & -.47 & .61 & .74 & .92 \\
\hline
\end{tabular}


Table 4: Mediation Analysis

\begin{tabular}{|c|c|c|c|c|}
\hline Relationships & $\begin{array}{l}\text { Direct } \\
\text { Effects } \\
\text { without } \\
\text { Mediator }\end{array}$ & $\begin{array}{c}\text { Direct } \\
\text { Effect with } \\
\text { Mediator } \\
\text { (C.I.) }\end{array}$ & $\begin{array}{l}\text { Indirect } \\
\text { Effects } \\
\text { (C.I.) }\end{array}$ & $\begin{array}{l}\text { Mediation } \\
\text { Hypotheses }\end{array}$ \\
\hline $\begin{array}{l}\text { Positive Emotions - } \\
\text { Satisfaction - Intention } \\
\text { to Recommend }\end{array}$ & $.495^{*}$ & $\begin{array}{c}.196^{*}(.107 \text { to } \\
.287)\end{array}$ & $\begin{array}{c}.287^{*}(.226 \\
\text { to } .362)\end{array}$ & Supported \\
\hline $\begin{array}{l}\text { Negative Emotions - } \\
\text { Satisfaction - Intention } \\
\text { to Recommend }\end{array}$ & $-.304^{*}$ & $\begin{array}{c}-.169^{*}(-.254 \\
\text { to }-.098)\end{array}$ & $\begin{array}{c}-.139^{*}(-.201 \\
\text { to }-.088)\end{array}$ & Supported \\
\hline $\begin{array}{l}\text { Positive Emotions - } \\
\text { Place attachment- } \\
\text { Intention to } \\
\text { Recommend }\end{array}$ & $.495^{*}$ & $\begin{array}{c}.263^{*}(.144 \text { to } \\
.388)\end{array}$ & $\begin{array}{l}.011(-.076 \\
\text { to } .098)\end{array}$ & Not supported \\
\hline $\begin{array}{l}\text { Negative Emotions - } \\
\text { Place attachment- } \\
\text { Intention to } \\
\text { Recommend }\end{array}$ & $-.304^{*}$ & $\begin{array}{c}-.176^{*}(.-.264 \\
\text { to }-.101)\end{array}$ & $\begin{array}{c}.002(-.013 \\
\text { to } .018)\end{array}$ & Not supported \\
\hline
\end{tabular}

